\title{
Friedrich Engel-Janosi
}

In the very human summation of the eight decades of his life, Friedrich Engel-Janosi wrote in his memoirs in 1974 that it seemed to him that, all in all, "he saw nothing that he had done that should make him feel ashamed--mistakes, failures, regrets, to be sure, but nothing about which to be ashamed. It is something, even if not much." In the same context, he also did not judge the value of his former relations with people just by the not too large number of contacts he had maintained for all these years.'

To this is to be added that Engel-Janosi, the son of a member of a Jewish industrial family coming from Hungary and a doyen of Austrian historians, who was born in Ober-Döbling, in Vienna, exercised a fascinating attractiveness, particularly over young people, until he died on March 7, 1978. Young people admired and loved him and frequently visited his home, where for four decades his first wife, Carlette, and, following her death shortly after their return from the United States, his second wife, Christiane, stood beside him as charming hostesses and conversationalists. That his wide knowledge, his scholarly abilities, and his descriptive powers had not declined even in advanced age are evidenced by the articles and reviews he wrote and published up to a few weeks before his death. As editor of the Austrian monthly periodical, Zeitgeschichte, I am proud of the fact that both the fourth and fifth volumes (1976-1978) contain scholarly essays written by him. Still others were planned.

In his often passionate discussions with younger historians or with specialists in other fields, including the natural sciences and the arts, in which he was interested because of his insatiable thirst for knowledge, the freshness of his spirit, his commitment, and his ability to make contacts were particularly conspicuous. His friends were unaware that he was eighty-five years old until his last illness a few weeks before his death. In his conversations he seemed ageless. The deep concern and sorrow of his youngest students over his death are clearly expressed in the necrology by Hertha Nagl-Docekal and Edith Saurer in Zeitgeschichte, Vol. V (1977-1978), pp. 396-399.

In the collection of Engel-Janosi's scholarly essays on Austrian foreign policy published on the occasion of his seventieth birthday, ${ }^{2}$

\footnotetext{
${ }^{1}$ Friedrich Engel-Janosi, . . aber ein stolzer Bettler. Erinnerungen aus einer verlorenen Generation (Graz: Verlag Styria, 1974), p. 295.

${ }^{2}$ Friedrich Engel-Janosi, Geschichte auf dem Ballhausplatz. Essays zur Österreichischen Außenpolitik 1830-1955 (Graz: Verlag Styria, 1963), pp. 307-322.
} 
Fritz Fellner, in his highly esteemed portrait of Engel-Janosi, has provided us with a detailed description and assessment of his life up to 1963. Consequently, in this particular tribute attention will be directed first and foremost to Engel-Janosi as a human being, a portrait which will conclude with a detailed discussion of what he wrote in his memoirs about what history has come to mean to him.

A few words were devoted to Engel-Janosi's background at the beginning of this essay. To this might be added that his paternal grandfather, Adolf Engel, was born in 1820 in Fünfkirchen (Pécs). Since Adolf's father, through a series of unfortunate circumstances, had lost all the property he had acquired as a grain dealer, he literally had to begin building up the family fortune from nothing. A highly gifted man, who left school at the age of eleven to earn his own way as a retailer and who learned German, Hungarian, French, and Hebrew by himself, he was highly successful. In 1848-1849 he sided with the Hungarian revolutionaries. In the years that followed, his Jumber business was so thriving that he was able to buy the Janosi estate from Prince Alfred Montenuovo in 1880. The next year he built the first cement plant in that part of the country. Finally, he acquired Komló, which was the largest coal mine in Hungary. He made many reforms to promote the welfare of his workers. Raised to the rank of hereditary nobility in 1886, he added the name of his property to the name of Engel. In the same year he also moved to Vienna with his family, where he took up residence in a house in the Hofzeile.

The maternal grandfather, Heinrich Klinger, was a prosperous textile manufacturer; consequently, the financial position of Friedrich Engel-Janosi's parents was so secure that they and their brothers and sisters could pursue their intellectual and cultural interests. In addition to being involved in the lumber business, an uncle on his father's side of the family was a gifted musician, who had friendly contacts with the Wahnfried family and wrote plays. His son Richard died in the concentration camp at Mauthausen. Friedrich's father, who tried his hand as a dramatist, was acquainted with some of the best known actors of his time and knew Henrik lbsen quite well. In addition, he published statistical handbooks and studies on the national economy. No matter what happened, he insisted that both of his sons were to be well educated, particularly in legal studies, so that they could enter state service. Friedrich's energetic and, for that time, unusually athletic, mother looked after the physical and social needs of her three children. In the family's home at Hofzeile No. 12, which Gustav Mahler, Julius Bittner, Arnold Rosé, and the young Bruno Walter visited regularly, she organized a private course in dancing, in which, 
among others, the daughters of Gustav Mahler and Sigmund Freud participated. On the occasion of her hundredth birthday in 1970 she received a telegram from President Nixon wishing her good luck, whereupon she exclaimed: "That is very nice of Mr. Nixon, but I don't approve at all of his policy."

It is not surprising, therefore, that a son of such parents was strong-willed and unwilling to compromise. To be sure, Friedrich fulfilled his father's wish when, having passed with distinction his examination at the end of secondary school before the First World War broke out, he began to study law at the University of Vienna. However, it was definitely the pursuit of special interests, especially in the peripheral areas such as legal history and legal philosophy, as well as the fascination exerted on him by several professors and docents of the juridical faculty, among them Moriz Wlassak, Hans Kelsen (who wanted to make him his assistant after his graduation), and Eugen Böhm-Bawerk, that made his studies to meet the requirements for a doctorate of jurisprudence more than just a duty for him. His visit to Heidelberg, "the city of Troeltsch, Gundolf, Windelband, and Max and Alfred Weber," shortly before Francis Ferdinand's assassination had a significant influence on his future career.

After his return from Heidelberg, Engel-Janosi joined the army as a so-called "one-year volunteer." He served as an artillery officer on the Galician and Italian fronts until the end of the war. He was decorated numerous times. Among other awards, he received the great silver medal for bravery, of which he was always proud. Although his younger brother Rudolf was killed in Russia, his father did not pressure him to seek a livelihood after he completed his work for a doctorate in jurisprudence in 1919, even though the family fortune amounted to only houses and some land after the war and subsequent inflation. In 1921 he completed his requirements for a doctorate in philosophy. His dissertation, which was written under Alfred Francis Pribram's supervision, was on "Die Lehre vom Staat im vormärzlichen Osterreich." Even today some of his conclusions in the dissertation are cited in published articles. In addition to his main field of study, history, his secondary fields were early ancient history and Indian philosophy.

The double doctorate prompted the director of the Lombard and Escompte Bank, who had bought the family house in the Hofzeile (in which the Engel-Janosi family, however, was still allowed to live), to offer Engel-Janosi the position of secretary of the bank's administra-

${ }^{3}$ Engel-Janosi, . . aber ein slulzer Betller, p. 25.

+Mbid., p. 41. 
tive council. Because of the dwindling state of the family fortune, Friedrich accepted it. The job did not demand too much of him. Like Franz. Kafka, whose duties as an insurance official still allowed him time to write, the bank employee Engel-Janosi wrote historical works - until the bank collapsed in 1924. These works were received in professional circles with more than just a passing interest. Among them were an article on the early years of Prince Eugene and his first book. Soziale Probleme der Renaissance, which was published in 1924.

The collapse of the bank and the death of his father both occurred within a month of each other. Although-or perhaps precisely because - his father had never demanded that he take over the wood and parquet factory in the Heiligenstädterstraße, Friedrich, the only surviving child, turned down a Rockefeller Foundation grant arranged by Prof. Pribram and took charge. While Engel-Janosi was still alive he often said that the real director of the factory, which officially belonged to his mother and which was in a rather deplorable condition in 1924, was his enchanting, intelligent, capable French wife Carlette, whom he had married in 1921. Thanks to her efforts, he maintained, he could devote himself to research. His memoirs, however, give a somewhat different picture. To be sure, Carlette spent more time and exerted greater efforts at the factory than did her husband. However, a business whose labor force increased from six employees in 1924 to over a hundred in 1938 during the economic crisis which beset Vienna during these years did not owe its growth to Carlette's work alone. Also, its success was not due merely to its being able to take advantage of the extensive housing construction program of the city of Vienna during that period.

At any rate, one thing Engel-Janosi wrote in his memoirs proved to be right. In addition to being an industrialist who always took an active part in the cultural and intellectual life of Vienna, he continued his scholarly research so intensively that he published three more books before the end of 1938: Graf Rechberg. Vier Kapitel zu seiner und Österreichs Geschichte, which appeared in 1927; Der Freiherr von Hübner (1811-1892), which came out in 1933; and Die Jugendzeit des Grafen Prokesch von Osten, which was published in 1938. His volume on Rechberg was his "Habilitationsschrift," on the basis of which he received the "venia docendi" for modern history from the philosophical faculty of the University of Vienna in 1929. In 1935 he was accorded the title of "ausserordentlicher Professor."

In the spring of 1937 and in 1938 Engel-Janosi served as Austrian exchange professor in Rome, where he completed an inner transformation that had been nearly two decades in the making: he became a 
Catholic and remained one in the full sense of the word until his death. He was in Rome when Hitler's troops marched into Austria. He and Carlette immediately returned to Vienna, where his mother and nine-year-old daughter Madelaine were staying. Although his mother did not want to believe that anything terrible would happen and although nothing "bad" actually happened to the immediate family in 1938-1939, he sold the factory and accepted an offer from Johns Hopkins University to come there for one year as research associate. Until he was able to obtain a French visa in the spring of 1939, he continued to work as a consultant for the business he had previously owned, prepared for his trip, and, insofar as he was still permitted to use the archives, collected as much material as he could for the continuation of his book on Prokesch von Osten. On April 1, 1939, after having been thoroughly looted by Eichmann's emigration bureau, he left Austria alone. When he crossed the Swiss border his entire wealth amounted to 6.50 francs. On noting this, as a man who up to then had never suffered for lack of money, he remarked: "So, and now I am a beggar." From the dark compartment an unknown voice rejoined: "A proud beggar, however." This remark of a stranger, which Engel-Janosi selected as the title for his last book, remained unintelligible to this writer before she read his memoirs.

Engel-Janosi at first stayed with Swiss relatives of his wife for a few days. Later Carlette and Madelaine, who had the measles when he left Vienna, joined him there. After spending a brief time in France, the Engel-Janosis stayed in England with friends of the composer Egon Wellesz while waiting for an American visa. At the end of May, 1939, Engel-Janosi was invited to speak at Cambridge, where he remained for six months as a "lecturer." Finally, the American visa arrived, and the family left Europe. Friedrich began his teaching and research activities at Johns Hopkins quite soon after his arrival. From there he went to Catholic University, in Washington, D. C., where he was invited, in 1941, to serve two years as guest professor in modern European history. He remained there as full professor until he returned to Vienna.

While still in England Engel-Janosi had begun to analyze the archival materials he had gathered in Austria, and he published several articles on the results of his investigations. In the United States he was cut off from his sources. For this and other reasons he now turned his attention to a topic in the broader field of intellectual history: the history of historical writing. Two books on that subject were published in the United States: The Growth of German Historicism, 
which appeared in print in 1944; and Four Studies in Historical and Political Sciences, which was brought out in 1955. Although his professional activities were devoted entirely to scholarship, insofar as possible he also led an active social life and participated in numerous cultural enterprises. Particularly after the end of the war he invited all kinds of young Austrian scholars to his house and offered often isolated and homesick scholarship holders, for a few hours at least, an Austrian environment of high standard that generally no longer existed in Austria. Carlette, who after completing the requirements for an $M$. A. degree taught French and the history of art on the college level, assisted him on all these occasions as a charming and devoted hostess.

In 1949, after he had been away during a decade of extremely troubled world history, Engel-Janosi returned to Vienna on a Rockefeller Foundation grant. He gave lectures at the University of Vienna, some of them on the history of Europe since 1914. In other words, he taught contemporary history long before it became an established field in Austrian universities. He also returned to his beloved Haus-, Hof- und Staatsarchiv. It was there that I, then probably one of the youngest archivists in Austria, got to know him personally and learned to admire him. The fact that my many contacts with him between 1959 and 1964 became less frequent thereafter was due wholly to my own professional activities at Salzburg after 1964. Yet, I have to thank him, at least indirectly, for my own academic career. The first inkling 1 had that something might be in the offing came when I unexpectedly received an extremely positive and affirmative letter about a longer article of mine on "Österreichs Katholiken und der Nationalsozialismus" that had been published in Wort und Wahrheit-a monthly publication highly esteemed by Engel-Janosifrom P. Thomas Michels, OSB, president of the International Research Center at Salzburg. His longtime friend and fellow-emigrant Engel-Janosi had recommended to him the female Viennese archivist, who after 1961 was also docent for Austrian history, for the vacant post of director of the Institute for Contemporary Church History at Salzburg. 1 will always deeply regret the fact that, on account of my increasing professional responsibilities at Salzburg, I saw EngelJanosi only rarely on brief visits and neglected opportunities to engage in many stimulating discussions with him. My painful feeling of regret over these omissions on my part cannot be assuaged by the fact that, upon the unanimous recommendation of all the historians, the academic senate of the faculty of arts voted to award him an honorary doctorate. Engel-Janosi was pleased when he was informed about it, but death prevented him from personally accepting the honor. 
In 1949 Engel-Janosi had declined the offer of the chair for contemporary history at the University of Vienna mainly out of regard for his wife and daughter but also because the question of housing still had not been resolved. When he returned to the Austrian capital ten years later, the Austrian bureaucracy certainly did not show him its best side. Because he was sixty-six years old he was accorded all the rights of a full professor, but his actual status was that of an "honorary professor" and the question of his pension remained unresolved. This problem caused him many worries later on and in the end was resolved in everything but a satisfactory manner.

During his first postwar sojourn in Vienna Engel-Janosi began to examine the documents that were to form the foundation for his greatest publications, on which he worked for twelve years: Österreich und der Vatikan (1846-1918) (2 vols., 1958-60) and Vom Chaos zur Katastrophe (1971. Published in Italian translation in 1973 under the title Il Vaticano fra fascismo e nazismo). However much EngelJanosi would have disliked such a label, both are standard works and will remain such. Although his reminiscences about the nine and a half years he taught at the University of Vienna after 1959 are marked by a certain feeling of resignation, and although he no longer intended to let himself be treated as a "distinguished foreigner" after his final return, as he had been before ${ }^{6}$ his list of publications indicates how very fruitful these years in Vienna prior to his death actually were. ${ }^{7}$ The joint Austrian-Hungarian project involving the editing of the Austrian and Hungarian ministerial conference protocols for the years between 1848 and 1918 was initiated on the Austrian side by Engel-Janosi, and he wrote thoughtful and incisive introdisctions for the four volumes that have thus far appeared. The collection. which will not be completed until many years after his death, will be a monumental source for the history of the last decades of the Habsburg monarchy.

Engel-Janosi always remained indebted to the United States, where his mother and daughter continued to live after his return to Austria. He was grateful for his relatively secure existence there in difficult times and for the opportunity to engage in scholarly research and academic teaching free of all restrictions. He cherished the friendships and contacts which were of decisive importance to him, among which was his friendship with Ezra Pound, who he maintains was as impor-

Ibid., pp. 257-262 and 298 .

${ }^{7}$ See Engel-Janosi, Geschichte auf dem Ballhausplatz, pp. 323-327; Friedrich Enge!Janosi. Die Wahrheit der Geschichte (Vienna, 1973), pp. 272-274; and Gerald Stourzh's necrology in the Almanach der Österreichischen Akademie der Wissenschaften. No. 126, p. 368. 
tant to his own development and "de-provincialization" as were Ludwig Derleth and Eric Voegelin. ${ }^{8}$ Yet, although he by no means needed to be "de-provincialized," he would not have become an American even if he had remained in the United States until his death. He was too deeply rooted in Europe, especially in the Austrian monarchy, whose late-blooming culture had made a deep impression on him from his childhood. Moreover, his really meaningful human relationships took place in Vienna - with Carlette, with whom he shared forty years of happily married life, and with Christiane, who gave him fifteen years of love and marriage. Finally, the high point of his professional life was also reached in Vienna in 1965 when he served as president of the International Congress of Historical Sciences.

Friedrich Engel-Janosi was, in the fullest sense of the word, a gentleman of "the world of yesterday," of the vanished Danubian monarchy, whose spiritual heritage he passed on to many young people in his capacity of teacher and fatherly friend. He was a historian with a "feu sacré," who himself best described what history meant to him when he wrote:

Historical writing is beautiful. It is not so much a matter of carrying on research as of vision and preparation. The time spent in preparation can last long, sometimes very long. It includes everything that is today called methodology; although formerly the term 'basic knowledge' was the favorite term. In a word, it includes everything that is indispensable before the actual writing begins. A person must from the very outset be driven by a 'feu sacré;' otherwise he will not be able to keep his shoulder to the wheel-assuming that the initial stage now and then threatens to become extinguished.

Writing history is beautiful and worthy of human endeavor. Historical writing has very rarely been developed-as far as I know only in three areas: Israel, ancient Greece, and China. It is a part of that wonder, that wonder-about-oneself-view which the Greek philosopher put at the beginning of all philosophizing. I still know of no better definition than that in the words which Ranke wrote one hundred and fifty years ago: To want to know 'how it actually was.' But what is meant by 'actually?"

University of Vienna

ERIKA WEINZIERL

"Engel-Janosi, ... aber ein stolzer Bettler, p. 295.

${ }^{y}$ See ibid., p. 296. 